\title{
Escalating Risk of Metabolic Syndrome Imparted by Salivary Biomarker in Obese Children
}

\author{
Lorin E. Donovan, Elizabeth Janowitz, \& Joon Young Kim \\ Syracuse University, New York, USA
}

\begin{abstract}
Type 2 diabetes (T2D) is a chronic metabolic disorder characterized by a progressive loss of B-cell function relative to insulin resistance. Once thought to be an adult disease, T2D has emerged as an increasingly prevalent health concern in obese youth, suggesting that early identification of those who are at high-risk for T2D is critical. Traditionally, either fasting glucose and/or 2-hr glucose concentrations during an oral glucose tolerance test has been used to identify prediabetes (i.e., intermediate stage of T2D). However, the fact that multiple blood collections are required during the test hinders necessary screening of high-risk youth with obesity and metabolic syndrome, primarily due to the invasive methods (i.e., fear of needles). For this reason, there is increasing interest in salivary biomarkers that can identify metabolic abnormalities. Goodson et al. provided critical evidence for future use of salivary samples for T2D risk detection as investigating saliva-based inflammatory biomarkers in an at-risk population of children.
\end{abstract}

Keywords: Type 2 diabetes, salivary biomarkers, inflammation, Children

$\begin{array}{lr}\text { Article History } & \begin{array}{r}\text { Corresponding Author } \\ \text { Received } 16 \text { September } 2020\end{array} \\ \begin{array}{l}\text { Accepted } 10 \text { October } 2020 \\ \text { Published 31 January 2021 }\end{array} \\ \begin{array}{l}\text { Available online 19 February 2021 } 291 \text { syr.edu } \\ \text { https://doi.org/10.47544/johsk.2021.2.1.24 }\end{array} & \text { The David B. Falk College of Sport and Human Dynamics } \\ \text { Syracuse University, USA }\end{array}$

\section{Methods}

A total of 744 children (mean age 11 years) were divided into 4 groups based on their weight status using the ageand sex-standardized BMI z-score: underweight, normal healthy weight, overweight, and obese $(\mathrm{n}=186$ for each group). Fasting saliva samples were collected from all participants to examine 20 biomarkers and the biomarkers were analyzed on a Luminex 200 platform (Luminex Corporation, Austin, TX, USA).

\section{Results}

Of the 20 biomarkers tested, 16 showed no significant differences between obese and normal weight subjects. However, 4 biomarkers did show significant differences between obese and normal weight subjects. Salivary Creactive protein (CRP), a pro-inflammatory biomarker, was 6 times higher in obese youth compared with their normal weight peers (median $435 \mathrm{pg} / \mathrm{ml}$ vs. $76 \mathrm{pg} / \mathrm{ml}, \mathrm{P}<0.0001$ ) (Table 1). Salivary insulin and leptin showed a 3fold increase in obese children compared with their normal weight counterparts. Salivary adiponectin (anti-

\section{Journal of Health, Sports, \& Kinesiology | ISSN 2692-9864 | www.johsk.com}


| 2021 | Volume 2 | Issue 1 | The Journal of Health, Sports, and Kinesiology |

inflammatory biomarker and indicator of insulin sensitivity) concentration was $30 \%$ lower in overweight (median $2,981 \mathrm{pg} / \mathrm{mL}$ ) and obese $(2,798 \mathrm{pg} / \mathrm{mL})$ youth compared with normal weight $(4,083 \mathrm{pg} / \mathrm{ml}, \mathrm{P}<0.0001)$ (Table 1).

Table 1. Concentration of Insulin, C-reactive protein (CRP), Adiponectin and Leptin in the Saliva Supernatant of 744 Children by Body Weight Category and Sex.

\begin{tabular}{|c|c|c|c|c|c|c|c|c|c|}
\hline \multirow{3}{*}{$\begin{array}{l}\text { Underweight } \\
\qquad(n=186)\end{array}$} & \multirow{2}{*}{$\begin{array}{r}\text { Probe } \\
\text { Parameter } \\
\text { Unit } \\
M(64)\end{array}$} & \multicolumn{2}{|c|}{$\begin{array}{c}\text { Insulin } \\
\text { Median/Intraquartile } \\
\mathrm{pg} / \mathrm{m} / \text { Saliva }\end{array}$} & \multicolumn{2}{|c|}{$\begin{array}{c}\text { CRP } \\
\text { Median/Intraquartile } \\
\mathrm{pg} / \mathrm{m} / \text { Saliva }\end{array}$} & \multicolumn{2}{|c|}{$\begin{array}{c}\text { Apiponectin } \\
\text { Median/Intraquartile } \\
\text { pg/m/ Saliva }\end{array}$} & \multicolumn{2}{|c|}{$\begin{array}{c}\text { Leptin } \\
\text { Median/Intraquartile } \\
\mathrm{pg} / \mathrm{m} / \text { Saliva }\end{array}$} \\
\hline & & 39.17 & 48.63 & 56.64 & 92.32 & 4,421 & 6,424 & 0.01 & 5.31 \\
\hline & $F(122)$ & 34.30 & 38.02 & 61.99 & 182.74 & 5,060 & 4,573 & 0.01 & 3.22 \\
\hline Normal & M (93) & 39.39 & 45.38 & 73.01 & 153.75 & 4,220 & 5,303 & 1.06 & 4.77 \\
\hline$(n=186)$ & $F(93)$ & 44.70 & 54.38 & 77.15 & 186.95 & 3,994 & 5,052 & 0.63 & 4.61 \\
\hline Overweight & $M(93)$ & 80.39 & 88.74 & 177.46 & 311.93 & 2,402 & 3,785 & 1.06 & 3.26 \\
\hline$(n=186)$ & $F(93)$ & 76.25 & 87.13 & 281.39 & 516.54 & 3,322 & 3,639 & 2.41 & 5.03 \\
\hline Obese & $M(93)$ & 112.98 & 125.24 & 429.44 & 668.52 & 2,548 & 2,779 & 3.16 & 6.40 \\
\hline \multirow[t]{2}{*}{$(n=186)$} & $F(93)$ & 143.50 & 150.24 & 443.13 & $1,033.29$ & 3,062 & 3,752 & 3.70 & 6.41 \\
\hline & Age & \multicolumn{2}{|c|}{0.107} & \multicolumn{2}{|c|}{0.083} & \multicolumn{2}{|c|}{0.373} & \multicolumn{2}{|c|}{1.000} \\
\hline Wilcoxon & Sex & \multicolumn{2}{|c|}{0.337} & \multicolumn{2}{|c|}{0.028} & \multicolumn{2}{|c|}{0.471} & \multicolumn{2}{|c|}{1.000} \\
\hline Regression & Overweight & \multicolumn{2}{|c|}{$<0.0001$} & \multicolumn{2}{|c|}{$<.0001$} & \multicolumn{2}{|c|}{0.001} & \multicolumn{2}{|c|}{0.408} \\
\hline \multirow[t]{2}{*}{ P-value } & Obese & \multicolumn{2}{|c|}{$<0.0001$} & \multicolumn{2}{|c|}{$<0.0001$} & \multicolumn{2}{|c|}{$<0.0001$} & \multicolumn{2}{|c|}{$<0.0001$} \\
\hline & Underweight & \multicolumn{2}{|c|}{0.157} & \multicolumn{2}{|c|}{0.266} & \multicolumn{2}{|c|}{0.142} & \multicolumn{2}{|c|}{1.000} \\
\hline
\end{tabular}

Note. Regenerated the Table 2 from Goodson et al. (1). Summary statistics are median, interquartile range (N subjects). Probability levels for age, sex, overweight, obese, and underweight were computed by Wilcoxon regression relative to normal healthy weight children.

\section{Discussion}

Biomarkers provide essential information for understanding the etiology of diseases, treatment, and early intervention. Saliva sampling has been introduced into research as a potential indicator of T2D risk and correlations between serum and saliva samples have been identified. In this study, 4 biomarkers were identified that exhibit significant change with increasing body weight in a pediatric population (Goodson et al., 2014). This suggests that saliva could be a useful blood replacement for the study of metabolic complications of obesity in children.

\section{Critique}

In the face of COVID-19, this study is especially important in bringing awareness to the possible use of salivary biomarkers in determining potential risk for T2D and metabolic syndrome. With the limited in-person human research available currently, a new non-invasive, cost-effective, time-saving method is of the utmost importance in addition to the fact that at-home saliva collection is feasible for the research purpose (https://salimetrics.com/how-do-icollect-saliva/). Although Goodson et al. proved the utility of the saliva analysis for T2D risk, a lack of validation data against blood samples is considered significant obstacle for a solid conclusion from this study. The saliva samples need to be compared to their respective blood samples in order to validate its reliability as novel biomarker. Furthermore, it would be germane to see if salivary biomarkers can be used for testing effectiveness of any prevention and treatment of metabolic syndrome and T2D in youth populations.

\section{Journal of Health, Sports, \& Kinesiology | ISSN 2692-9864 | www.johsk.com}


| 2021 | Volume 2 | Issue 1 | The Journal of Health, Sports, and Kinesiology |

\section{Reference}

Goodson, J. M., Kantarci, A., Hartman, M. L., Denis, G. V., Stephens, D., Hasturk, H., ... \& Barake, R. (2014). Metabolic disease risk in children by salivary biomarker analysis. PloS one, 9(6), e98799. doi:10.1371/journal.pone.0098799

(C) 2021. This work is licensed under a CC BY-NC-SA 4.0 International license.

This is an open access article distributed under the Creative Commons Attribution License which permits unrestricted use, distribution, and reproduction in any medium, provided the original work is properly cited.

\section{Journal of Health, Sports, \& Kinesiology | ISSN 2692-9864 | www.johsk.com}

